\title{
教室における達成動機，目標志向，内発的興味， 学業成績の因果モデルの検討
}

\author{
同志社大学 田中あゆみ²・山内弘継
}

Causal models of achievement motive, goal orientation, intrinsic interest, and academic achievement in classroom Ayumi Tanaka and Hirotsugu Yamauchi (Department of Psychology, Faculty of Letters, Doshisha University, Karasuma, Imadegawa, Kamigyo-ku, Kyoto 602-8580)

This study investigated the effect of achievement motive on goal orientation, and that of goal orientation on intrinsic interest in learning and academic achievement, based on the model proposed by Elliot and Church (1997). A sample of 222 fifth and sixth grade students of an elementary school, and another of 307 seventh, eighth and ninth grade students of a junior high school participated in the study. The approach-avoidance framework of Elliot and Harackiewicz (1996) was used to classify goal orientations. With multiple-sample structural equation modeling, the paths in two causal models, one for each of the elementary and junior high school samples, were compared. $\mathrm{A}$ path was found from hope for success to mastery orientation, from both hope for success and fear of failure to performance-approach orientation, and from fear of failure to performance-avoidance orientation. Mastery and performance-approach orientations each had a positive effect on intrinsic interest in learning. For elementary school children, performance-approach orientation enhanced academic achievement, and for junior high school students, mastery orientation mainly facilitated it. Performance-avoidance orientation had a negative effect on both intrinsic interest and academic achievement.

Key words: goal orientation, achievement motive, intrinsic interest, academic achievement, structural equation modeling.

多くの研究者たちは共通して, 生徒が学習に対して もつ目標が二つの方向性に大別できることを認めてい る。一つは学習や理解を通じて能力を高めることであ り，マスタリー志向と呼ばれる。もう一つの目標は， 他者に対して相対的に優位になることで能力の高さを 誇示することであり，遂行志向と呼ばれる3.一般的 に，マスタリー志向はポジティブな遂行結果を導く望 ましい動機づけや認知の過程に関連するが，遂行志向 はネガティブな遂行結果を遂く不適切な動機づけや認 知の過程に関連すると考元られており（Wolters，Yu， \& Pintrich, 1996), 生徒のマスタリー志向性をいかに 発達させ維持させるかという点に関心が集中している (Ames, 1992).

しかしこれまでの研究のなかで遂行志向の性質に関

本稿は 1998 年度に同志社大学文学研究科へ提出した修士論 文をもとに加筆・修正したものである。

本研究にご協力いただいた小学校・中学校の先生方や児 童・生徒の皆様に対して心から御礼申し上げます。

Nicholls（1984）はこ机を課題関与志向（task-involved orientation) と自我関与志向 (ego-involved orientation) と称し, Dweck（1986）は学習志向 (learning orientation) と遂行志向 (performance orientation), Ames \& Ames (1984) はマスタリ 一志向 (mastery orientation) と能力志向 (ability orientation) と称したが, 本研究ではマスタリー志向と遂行志向という用話 を用いる。
して報告されている結果は一貫性に久けているといっ てよい。たとえば，生徒の自己知覚した能力や学業的 な自己効力感と遂行志向との間に負の相関を示す研究 もあるが (Ames \& Archer, 1988; Schunk \& Swartz, 1993)，正の相関を示吉研究も存在し（Wolters et al., 1996), 遂行志向は常に不適切な動機づけや認知の過 程と関連しているわけではない。このような矛盾か ら, 近年のいくつかの研究では, 従来の遂行志向とい う概念を新たな枠組みによってとらえ直すことを試み ている。

Elliot \& Harackiewicz（1996）は，伝統的に達成動 機の研究者たちが動機づけについて接近傾向と回避傾 向の側面から論じていたのに対し (McClelland, Atkinson, Clark, \& Lowell, 1953; Atkinson, 1957), 近 年の目標理論では接近傾向のみが扱われている点 (Ames, 1992; Duda \& Nicholls, 1992), あるいは接近 傾向と回避傾向が独立して扱われていない点 （Dweck, 1986）を指摘した. 彼らは遂行志向を，自分 の有能さを誇示しポジティブな評価を得ようとする遂 行接近 (performance-approach) 志向と, 自分の無能 さが明らかになる事態を避けネガティブな評価を回避 しょうとする遂行回避（performance-avoidance）志 向に分類し, 接近傾向と回避傾向を区別した。气し て, 課題遂行に際してマスタリー目標条件, 遂行接近 目標条件, 遂行回避目標条件を操作した実験を行った 
ところ, 遂行回避目標条件の者は, 遂行接近目標条件 やマスタリー目標条件の者より課題を楽しいと感じる 程度が有意に低く, 接近と回避による分類の有効性を 示す結果となった。

この研究をさらに広げ, Elliot \& Church (1997) は 大学生を対象に, 実際の教室場面で三つの目標志向が 学習への内発的興味や学業成績に及ほす影響を探ると ともに，三つの目標志向を規定する要因について検討 している。彼らは要因の一つとして, 達成に関連する 動機の傾性 (disposition) である成功願望と失敗恐怖 に着目した。成功願望は，“達成したときに誇りを体 験できる能力”（Atkinson，1964）と定義されるよう に，人を成功に接近させる傾性である。マスタリー志 向と遂行接近志向は，ポジティブな結果の獲得に注目 し接近への自己調整をするために，成功願望に基づく と予想できる。一方, 失敗恐怖は, “目標が達成でき なかったときに恥を体験できる能力” (Atkinson, 1964）と定義されるように，人に失敗を回避させる傾 性である。遂行回避志向はネガティブな結果の回避に 注目し回避の自己調整をするために，失敗恐怖に基づ くと予想できる。また Middleton \& Midgley (1997) は，Elliot らと同様の分類に基づいた目標志向の研究 のなかで，遂行接近志向とテスト不安の間に正の相関 を見いだしていることから，遂行接近志向は，接近の 動機と同時に回避の動機にも関連している可能性が考 えられる。これは, 遂行接近志向が, ネガティブな結 果を回避するためにポジティブな結果に接近するとい う“積極的回避 (active avoidance)” (Gray, 1987) の 役目も果たすことを示唆している. Elliot \& Church （1997）は三つの目標志向を基準変数として重回帰分 析を行い，マスタリー志向は成功願望で，遂行回避志 向は失敗恐怖で, 遂行接近志向は成功願望と失敗恐怖 の両方から予測されることを示した。

接近への動機づけは, 達成状況を挑戦として知覚さ せ，課題に情動的・認知的に没頭させるような過程を 導くと考えられており，学習に対する内発的興味を促 進すると考えられる. 対照的に, 回避への動機づけ は，失敗に関連した情報へ敏感にさせ，評価に対する 不安を強める過程を引き起こすとされており, 内発的 興味を抑制すると考朰られ。. Elliot \& Church （1997）は内発的興味がマスタリー志向から正の影響 を, 遂行回避志向から負の影響を受けていることを見 いだしたが，遂行接近志向との有意な関連は見いださ なかった。しかし Skaalvik（1997）のように，遂行 接近志向に対応する自己高揚的自我志向 (selfenhancing ego orientation) の内発的興味に対する正 の影響を報告している研究もある。

Covington \& Roberts (1994) は，失敗恐怖が強く 自分の能力に自信のない生徒は, 自己価值の感覚を守 るために, 努力の差し控えやセルフ・ハンディキャッ
ピング，遅延といった方略を取りやすいと述べてい る。このような自己防衛的な過程がともなうであろう 遂行回避志向は, 学業成績を低下させると考えられ る. 一方，マスタリー目標志向および遂行接近志向と 学業成績の関連は, “学校教育における評価システム の問題点をうかがわせる”（伊藤，1995，p.82）面で 目標志向の研究において議論の的となっている. マス タリ一志向の高い学習者は, 水準の浅い学習方略（暗 記など）よりも深い方略（文の意味を理解することな ど）をより多く使用する傾向がみられるが, 実際の学 習結果との関連は十分に見いだされていない（Nolen, 1988)。わが国の研究でも, Hayamizu, Ito, \& Yoshizaki（1989）は，マスタリー志向が非競争的で理解志向 という望ましい学習活動と結びついているにもかかわ らず，実際の学業成績とは正の関係がなく，よい成績 を取りたいという遂行志向のほうが実際に高い成績に 結びついていたことを報告している. Elliot \& Church （1997）は大学生の学業成績が遂行接近志向から正の 影響を, 遂行回避志向から負の影響を受けていること を見いだしたが，やはりマスタリー志向と成績との有 意な関連は見いださなかった。

Elliot \& Church（1997）を含めこれまでの研究の多 くは, 生徒の学業達成の指標として 1 回きりのテスト の得点や特定の教科の成績を使用している。しかし個 人内で変動の大きい 1 回のテストの得点で生徒の実力 を正確にとらえるのは困難であり，また，一つの教科 のみを対象にすると，その教科の得意不得意などに大 きく左右されてしまう。そこで本研究は, 総合的な視 点に基づく各生徒の学力の評価を担任教師に依頼し た。この指標には, 生徒のより広範囲の学業達成度が 反映されるのではないかと考えられる。

本研究の目的は，第一に Elliot \& Church (1997) に基づき三つの目標志向（マスタリー志向，遂行接近 志向, 遂行回避志向）を測定し, 彼らの概念化の妥当 性を確認することである。第二に，成功願望と失敗恐 怖が三つの目標志向を規定し, 目標志向が学習への内 発的興味や成績に影響を及ぼすというElliot \& Church（1997）が大学生をサンプルに検討した因果 モデルを我が国の小・中学生に適用し, 彼らと同様の 結果が得られるか, そして授業や評価のシステムなど が大きく異なる小学生と中学生で変数間の関係に違い がないか検討することを目的とした。そして本研究で は生徒の学業成績の指標に担任教師による総合評価を 用いることから, 従来の研究とは異なる視点から目標 志向と成績との関係を探ることができるのではないか と予測された。

\section{方 法}

被調査者 被調査者は愛知県の公立小学校 5,6 年 生 9 クラスの児童 313 名, 公立中学校の $1,2,3$ 年生 
Table 1

目標志向尺度の確認的因子分析の結果

\begin{tabular}{|c|c|c|c|c|}
\hline 番号 & 質 問 項 目 & 因子 1 & 因子 2 & 因子 \\
\hline \multicolumn{5}{|c|}{ (マスタリー目標志向) } \\
\hline I5 & 授業中は，できるだけたくさんのことを勉強したいと思います。 & 0.65 & & \\
\hline I11 & $\begin{array}{l}\text { 授業の内容をできるだけしっかりとわかるようにすることは，わたしにとって大切なこ } \\
\text { とです. }\end{array}$ & 0.64 & & \\
\hline 117 & $\begin{array}{l}\text { わたしは，授業の内容について，もっと詳しく知りたいとか，もっとほかのことも知り } \\
\text { たいと思うことがあります。 }\end{array}$ & 0.65 & & \\
\hline $\mathrm{I} 23$ & わたしは，授業の中で先生がいうことはできるだけきちんと聞こうと思います。 & 0.63 & & \\
\hline $\mathrm{I} 29$ & 授業では，簡単な内容より，少し難しくても面白い内容をするほうが好きです。 & 0.49 & & \\
\hline I35 & わたしは，少し難しくても新しいことを勉強するほうが好きです。 & 0.59 & & \\
\hline \multicolumn{5}{|c|}{ （遂行接近目標志向） } \\
\hline I6 & ほかの人よりよい点数をとることは，わたしにとって大切なことです。 & & 0.65 & \\
\hline $\mathrm{I} 12$ & 学校では，ほかの人よりよい成績をとることを目標にしています。 & & 0.71 & \\
\hline I18 & 学校では，がんばってほかの人にわたしがよくできることをみせたいと思います。 & & 0.60 & \\
\hline $\mathrm{I} 24$ & まわりのみんなよりもよい成績をとろうと思うと，わたしはやる気が出ます。 & & 0.70 & \\
\hline 130 & みんなより勉強がよくできるとよいと思います。 & & 0.62 & \\
\hline I 36 & $\begin{array}{l}\text { 家族や友達やほかの人たちによくできると思われるように，よい成績をとりたいと思い } \\
\text { ます. }\end{array}$ & & 0.78 & \\
\hline \multicolumn{5}{|c|}{ （遂行回避目標志向） } \\
\hline $\mathrm{I} 2$ & “悪い成績をとってしまったらどうしよう”と考えることがよくあります. & & & 0.58 \\
\hline 18 & わたしは, テストでほかの人より悪い点数をとってしまうことが心配です. & & & 0.61 \\
\hline $\mathrm{I} 20$ & わたしは，ほかの人より悪い成績をとらないようにしたいと思います. & & & 0.81 \\
\hline 126 & 先生に変な質問をして，わたしの頭が悪いと先生に思われるのがいやです。 & & & 0.54 \\
\hline
\end{tabular}

12 クラスの生徒 430 名の計 743 名であった.このう ち, 第 1 回, 第 2 回の両調査に出席し, いずれの調査 にも欠損值のなかった小学生 222 名（男子 109 名, 女 子 113 名), 中学生 307 名（男子 160 名, 女子 147 名) の計 529 名を分析の対象とした。

質問紙（a)目標志向の尺度：Elliot \& Church （1997）が作成した 18 項目の達成目標質問紙を翻訳 し，小・中学生が理解できるように項目の表現を検討 した上で使用した。これはマスタリ一志向, 遂行接近 志向，遂行回避志向について各 6 項目で構成される. 項目の内容は Table 1 に示した. (b) 成功願望と失敗 恐怖の尺度：Gjesme \& Nygård（1970）の30 項目か らなる The Achievement Motives Scaleを翻訳して用 いた．伝統的な達成動機理論に基づくこの尺度は，ド イツ語版やオランダ語版，ロシア語版，中国語版など 多くの言語に翻訳されて利用されており，その信頼性 と構成概念的妥当性は広く認められている（Man, Nygård, \& Gjesme, 1994). 本研究では, 小・中学生が 理解できるように項目の表現を検討し，成功願望と失 敗恐怖について各 6 項目を選び使用した。項目内容は Table 2 に示した. (c)内発的興味の尺度：Elliot \&
Church（1997）が使用した 8 項目を参照し，6 項目か らなる尺度を作成した。項目内容はTable 3 に示し た. 以上の尺度はいずれも，“全然あてはまりません” から“すごくあてはまります”までの6 件法で評定を 求め, あてはまる程度が強いほど高得点になるように 1 点から 6 点までの得点を配分した。

学業成績 各児童・生徒の総合的な成績の指標を得 るため, 学校側の協力を得て各学級の担任教師に“こ の生徒の今学期の成績は, 主要教科を平均すると, だ いたいどのような程度であったと招考えですか”とい う項目について “非常に悪い成績だった”から“非常 によい成績だった”までの7件法で，また“この生徒 が将来進学し，より高等な教育を受けるときには，成 績はどのようであると考えられますか”という項目に ついて “非常に悪い成績だろう”から“非常によい成 績だろう”までの 7 件法で回答を求めた. 評定の際に は，7段階で人数を均等にすることなどの配分を特に 求めなかった。

実施時期および手続き 調査は 2 回の時期に分けて 行われた。第 1 回調查は 98 年 6 月に行われ, 成功願 望と失敗恐怖の尺度と目標志向の尺度を実施した。第 
Table 2

達成動機尺度の確認的因子分析の結果

\begin{tabular}{|c|c|c|c|}
\hline 番号 & 質 問 項 目 & 因子 1 & 因子 2 \\
\hline \multicolumn{4}{|c|}{ (成功願望) } \\
\hline I1 & $\begin{array}{l}\text { わたしは，うまくやれるかどうかわからないような難しいことにチャレンジする } \\
\text { のが好きです。 }\end{array}$ & 0.56 & \\
\hline 17 & わたしは, 自分にとってけっこう難しい問題はやってみたくなります. & 0.82 & \\
\hline I13 & $\begin{array}{l}\text { わたしは，自分の能力を試すことができるような状況では，チャレンジしようと } \\
\text { いう気になります. }\end{array}$ & 0.83 & \\
\hline 119 & $\begin{array}{l}\text { わたしは，何か難しいことに挑戦するとき，たとえ何かの役に立つとはいえない } \\
\text { ときでも，熱中してしまいます. }\end{array}$ & 0.66 & \\
\hline 125 & わたしは自分の能力を試すような場面には一生懸命になります。 & 0.50 & \\
\hline $\begin{array}{l}\text { I31 } \\
(\text { 失 }\end{array}$ & $\begin{array}{l}\text { わたしは，全力をつくせば解決できる問題に挑戦するのが好きです。 } \\
\text { 敗恐怖） }\end{array}$ & 0.73 & \\
\hline I4 & $\begin{array}{l}\text { 最後にどうなるかよくわからない状況では，わたしは失敗しないかと不安になり } \\
\text { ます. }\end{array}$ & & 0.45 \\
\hline 110 & わたしは，自分がきちんとできるかどうかわからないことには心配になります。 & & 0.44 \\
\hline 116 & $\begin{array}{l}\text { わたしは，自分が最後まできちんとできるかどうかわからないし，ほかの誰もそ } \\
\text { れについて知らないようなことをするのはいやです。 }\end{array}$ & & 0.65 \\
\hline $\mathrm{I} 22$ & わたしは，自分の能力が試されるようなときには不安になります。 & & 0.77 \\
\hline I34 & わたしは，すぐにはよくわからない問題に出あうと不安になります. & & 0.76 \\
\hline
\end{tabular}

Table 3

内発的興味尺度の確認的因子分析の結果

\begin{tabular}{|c|c|c|}
\hline 番号 & 質 問 項 目 & 因子 1 \\
\hline M1 & わたしは，勉強するのはおもしろいと思います & 0.87 \\
\hline $\mathrm{M} 2$ & わたしは，授業をうけるのは抏もしろいと思います & 0.76 \\
\hline M4 & わたしは, 勉強するのが好きです & 0.86 \\
\hline M5 & わたしは，勉強が退屈です（逆転項目） & 0.63 \\
\hline M6 & わたしは，勉強するのは楽しいことだと思います & 0.89 \\
\hline
\end{tabular}

2 回調査は98 年 7 月に行われ，内発的興味の尺度を 実施した。調査は“日常生活のアンケート”というか たちで担任によって学級ごとに実施された。7月に行 われる学期末の一連のテストが終了した後に担任の教 師が各生徒の成績評価を行った。

\section{結果}

尺度の妥当性 目標志向尺度，成功願望と失敗恐怖 の尺度，抒よび内発的瞘味の尺度の妥当性を確認する ために，各尺度について小・中学生のサンプル全体を 対象に確認的因子分析を行った ${ }^{4}$. 分析にはSASの CALIS を使用し，最尤推定法により母数の推定を行 った。目標志向尺度と成功願望と失敗恐怖の尺度につ いては，それぞれ因子間の相関を仮定した。

目標志向尺度の確認的因子分析の結果，マスタリー 志向，遂行接近志向，遂行回避志向の 3 因子モデルを
確認した。因子負荷量の低かった遂行回避志向尺度の 2 項目を削除したところモデルの適合度に改善がみら れ，これを最終的な結果として Table 1 に示した。毛 デルの説明力を表す適合度指標 GFI (goodness of fit index）の值は.88であり，3 因子モデルは標本共分散 行列を $88 \%$ 説明していた。修正適合度指標 AGFI (adjusted goodness of fit index) の值は.83であった。 標本サイズと母数の数を考慮すればモデルのデータと

\footnotetext{
4 確認的因子分析は，小・中学生の各サンプルを対象にした 分析も行った。それぞれの適合度は，目標志向尺度では小学生 に対 $L \mathrm{GFI}=.85, \mathrm{AGFI}=.80$, 中学生に対し $\mathrm{GFI}=.87, \mathrm{AGFI}$ $=.82$, 達成動機尺度では小学生に対し $\mathrm{GFI}=.91, \mathrm{AGFI}=.86$, 中学生に対 $L G F I=.90, A G F I=.85$, 内発的興味尺度では小学 生に対 $L \mathrm{GFI}=.96, \mathrm{AGFI}=.89$, 中学生に対 $L \mathrm{GFI}=.99$, AGFI=.98であった。
} 
Table 4

各尺度の平均値, 標準誤差, Cronbach $の \alpha$ 係数

\begin{tabular}{lcccc}
\hline 尺度 & 小学生 & 中学生 & 全体 & $\alpha$ 係数 \\
& $N=222$ & $N=307$ & $N=529$ & \\
\hline 成功願望 & 4.05 & 3.77 & 3.89 & 0.84 \\
& $(0.08)$ & $(0.06)$ & $(0.05)$ & \\
失敗恐怖 & 3.11 & 3.62 & 3.41 & 0.75 \\
& $(0.08)$ & $(0.06)$ & $(0.05)$ & \\
マスタリ一目標 & 4.28 & 4.06 & 4.16 & 0.78 \\
& $(0.07)$ & $(0.05)$ & $(0.04)$ & \\
遂行接近目標 & 3.81 & 3.81 & 3.81 & 0.77 \\
& $(0.09)$ & $(0.06)$ & $(0.05)$ & \\
遂行回避目標 & 3.55 & 3.80 & 3.69 & 0.75 \\
& $(0.09)$ & $(0.07)$ & $(0.05)$ & \\
内発的興味 & 3.47 & 3.12 & 3.27 & 0.90 \\
& $(0.09)$ & $(0.06)$ & $(0.05)$ &
\end{tabular}

注）カッコ内の数值は標準誤差を示す.

の適合は良好であったといえる。

成功願望と失敗恐怖の尺度の確認的因子分析から,

2 因子モデルを確認した。負荷量の低かった失敗恐怖 の 1 項目を削除し, 最終的な結果として Table 2 に示 した，モデルの適合度は良好で， GFI = .92, $\mathrm{AGFI}=$ .88 であった.

内発的興味尺度の確認的因子分析の結果，1因子モ デルが確認されたが, 負荷量の低かった 1 項目を除い たところ適合度はさらに上昇した。最終的な結果を Table 3 に示した。適合度は $\mathrm{GFI}=.98, \mathrm{AGFI}=.95$ と高い值が得られた。

基礎統計量 各尺度の Cronbach の $\alpha$ 係数と, 小学 生・中学生抢よび全体についての平均值, 標準誤差を Table 4 に示した. $\alpha$ 係数は.75 から. 90 の範囲にあ り, 尺度には十分な内的整合性が認められた。各尺度 の小学生と中学生の平均得点を, 1 要因の分散分析を 用いて比較した。その結果, 中学生に比べて小学生 は, 成功願望やマスタリー志向, 内発的興味の平均得 点が有意に高く（それぞれ $F(1,527)=8.73, p<.01 ;$ $F(1,527)=6.99, p<.01 ; F(1,527)=11.26, p<$ $.001)$, また小学生より中学生のほうが失敗恐怖と遂 行回避志向の平均得点が有意に高かった $(F(1,527)$ $=28.61, p<.001 ; F(1,527)=5.17, p<.05)$. 遂行接 近志向尺度には有意な得点差が認められなかった。

次に，三つの目標志向間の関係を調べるために相関 係数を算出した。 マスタリー志向と遂行接近志向は 小・中学生ともに中程度の相関があった（小学生 $r=$ .39, 中学生 $r=.38)$. マスタリ-志向と遂行回避志向 の間にも正の相関があり, 中学生のほうが小学生より もやや相関が高かった（小学生 $r=.19$, 中学生 $r=$
.31)。しかし相関の有意差検定を行ったところ，この 相関の差は有意ではなかった。遂行接近志向と遂行回 避志向は小・中学生ともにやや高い正の相関関係がみ られた (小学生 $r=.67$, 中学生 $r=.63$ ).

構造方程式モデリング 成功願望と失敗恐怖が目標 志向を規定し, 目標志向が学習への内発的興味や学業 成績に影響を及ぼすというElliot \& Church（1997） の因果モデルを，構造方程式モデルの推定によって検 討した。潜在変数の構成には, 確認的因子分析で因子 負荷量の高かった項目（4から 5 項目）を観測指標と した。潜在外生変数となる成功願望と失敗恐怖の間に 共分散を仮定し，また遂行接近志向と遂行回避志向に やや高い相関があったことを考慮してこの二つの潜在 変数の誤差にも共分散を仮定した。

小学生と中学生で潜在変数の関係性に違いがないか どうかを検討するために, 用いる観測変数と潜在変 数, またパスの配置や拘束条件を共通とした上で, 多 母集団の同時分析モデルの構築によるサンプル群間比 較を行った（豊田，1992）。同時分析モデルを構築す る際に次の二つの制約を入れた。（a)構成概念の解釈 的な意味がサンプル間で一致するように，因子負荷量 がサンプル間で等しい，(b)成績評価の 2 項目の誤差 は両サンプルで等しい。これをモデル 1 とし，何も制 約を入れないモデル，つまりすべての母数がサンプル 間で異なるとするモデル（モデル2）と比較した。分 析ソフトは EQS (Bentler, 1995) を使用し, 最尤推定 法を用いて解を求めた。

二つのモデルの全体的評価を比較すると，モデル 1 は $\chi^{2}(d f=695)=1447.18, \mathrm{AIC}=57.18$, モデル 2 は $x^{2}(d f=672)=1419.21, \mathrm{AIC}=75.21$ であり，赤池情 報量規準 AIC (Akaike's information criterion) の値 が小さいモデル1のほうがモデル2よりよいモデルで あるといえる。ラグランジュの乗数検定によって等価 の制約の妥当性を検定したところ, 成績を測定する二 つの観測指標のうち，自由母数とした項目 1 (“この 生徒の今学期の成績は, 主要教科を平均するとだいた いどの程度であったか”) の因子負荷量に対する等価 の制約が不適当であることが示されたため，この制約 をモデルから除いた。修正されたモデルの主な適合度 指標は, $\varkappa^{2}(d f=694)=1440.77, \mathrm{AIC}=52.76, \mathrm{GFI}=$ .84, $\mathrm{AGFI}=.81, \mathrm{RMSEA}=.045$ であり，説明率に問 題はないと判断した. Figure 1 亿標準化された解を 示した。

達成動機から目標志向への因果係数は小・中学生で ほぼ類似しており，Elliot\& Church（1997）の示した 結果と同様の傾向が本研究でも認められた。ママスタリ 一志向は, 成功願望から強い影響を（小学生.79, 中 学生.76), 失敗恐怖から弱い影響を受けており（小学 生.41, 中学生.38), 成功に接近する動機に大きく規 定されていたといえる. 対照的に遂行回避志向は失敗 
恐怖から強い影響を(小学生.87, 中学生.81), 成功 願望から弱い影響を受けて抢り（小学生.30, 中学生 .28), 失敗を回避する動機に大きく規定されていたと いえる。一方，遂行接近志向は成功願望と失敗恐怖の 両方からほぼ等しい強さの影響を受けていた（小学生 .55 と.62, 中学生. 45 と.45).

次に目標志向から学習に対する内発的興味への因果 係数をみると, マスタリー志向および遂行接近志向が 内発的興味に大きな影響を与えていた。学生ではマ スタリー志向と遂行接近志向からの影響がほぼ等しい のに対し (.59と.62), 中学生ではマスタリー志向か らの影響のほうがやや強く表れていた（.70と.49）. 遂行回避志向は小・中学生ともに内発的興味に負の影 響を及ぼしていた（小学生がー.75, 中学生がー.56).

目標志向と成績との関係をみると，小・中学生とも に遂行回避志向が成績に負の影響を与えており，この 負の影響力は小学生のほうが強かった（小学生が -.65, 中学生がー.36). 遂行接近志向およびマスタリ 一志向と成績との関係は，両サンプルで大きく異なっ ていた。学生においては遂行接近志向が成績に影響 を与えて抲り (.62), マスタリ一志向とは有意な関連 がみられなかった (.03). 一方中学生に掞いてはマス タリ一志向から成績に有意な影響があり (.37), それ は遂行接近志向からの影響力（.27）を上回っていた。

\section{考察}

本研究は, Elliot \& Harackiewiez（1996）の接近と 回避の枠組に基づく目標志向の概念化の妥当性を確認 的因子分析により確認した。構造方程式モデリングに よると, 遂行接近目標志向と遂行回避目標志向は他の 変数と異なる関連を示した。ここから，一貫性に欠け ていた従来の研究結果を説明することができるだろ う。

学習そのものより自己に注目する遂行志向におい て, 能力の高さの誇示というポジティブな結果に接近 する遂行接近志向は, 学習への内発的興味や成績にポ ジティブな影響があった。この遂行接近志向に対し て, 成功願望と失敗恐怖が同程度の規定力をもってい た. Covington \& Omelich (1991) は, 成功への要求 と失敗不安の両方の性質を共有している者を“過努力 者 (overstrivers)” と称し，自分の能力に確信がもて ないため常に不安を経験しながら，成功することで自 己価值を再保証しようとする者であると記述してい る.このように不安によって努力が促進されることか ら学習行動が効果的に行われていると考えられる。本 研究では特に, 構造モデルで得られた数值を比較する と, 小学生における遂行接近志向加ら内発的興味や成 績への影響力のほうが中学生よりも大きかった。小学

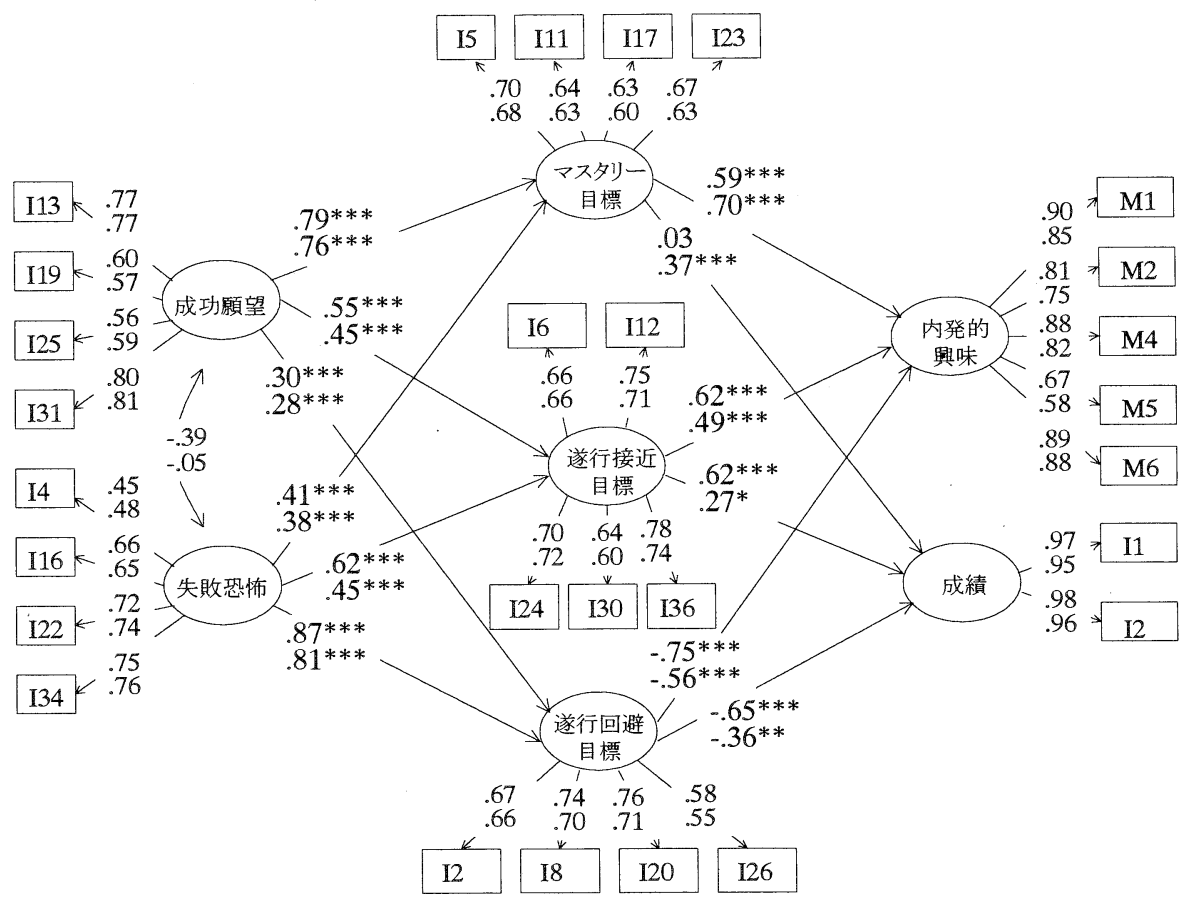

Figure 1. 達成動機, 目標志向, 内発的興味, 学業成績の因果モデル。上段に 小学生の, 下段に中学生の数值を示した。双方向の矢印は相関を意味する. ${ }^{*} p<.05,{ }^{* *} p<.01,{ }^{* * *} p<.001$. 
生が学習に興味をもつきっかけは，学習そのものへの 興味ではなく, 学習して自分の有能さを他人に承認さ れるという結果に興味をもつことにあり，そのような 自己への関心の力が純粋な知的好奇心の力よりも強い 推進力をもって学習活動へ動機づけているのかもしれ ない.これは, 遂行接近志向と内発的興味とのポジテ イブな関連性が，大学生を対象としたElliot \& Church（1997）の研究では見いだされていないが，6 年生から 8 年生の子どもを対象にした Skaalvik （1997）の研究で見いだされていることからもいえる のではないか，また成績については，遂行志向は暗記 やリハーサルといった浅い過程の学習方略との関連が 報告されているが, 小学生はこの浅い過程の学習方略 のほうがよりよい成績につながっているとも考えられ る。

中学生の内発的興味や成績には，マスタリー志向か らの影響力のほうが遂行接近志向からの影響力より大 きかった. 中学校では, 学習する内容がより複雑にな るため, 学習が自尊心の高揚の手段である遂行接近志 向の生徒より，学習過程そのものを目的とするマス夕 リ一志向の生徒のほうが, 総合的にみられる場合に教 師によってはっきりと評価されるような着実な学業遂 行を示しているようだ。この点で本研究はマスタリー 志向の適応的な性質を明確に確認した。従来のほとん どの研究と同様に, Elliot \& Church (1997) の研究で は，人格心理学の議義におけるマスタリー志向と成績 の間に有意な関係を認めなかった。また Skaalvik （1997）もマスタリー志向と数学のテスト得点の間に 有意な関係を見いだしていない.したがってマスタリ 一志向から導かれるのは，なんらかのテストなどに即 時に結果が表れるような学習活動ではないことが推測 できる。

遂行志向に扔いて，ネガティブな結果を回避する性 質のみが不適切な動機づけや認知の過程に関連するよ うだ。遂行回避志向は学習への内発的興味と成績にネ ガティブな影響を与えていた。 今までの目標志向の研 究では, 回避目標や回避行動は, 接近の目標や接近行 動と比較してあまり注目されていなかったが, 本研究 の結果は, ネガティブな評価を回避する目標志向や, この志向を規定する失敗恐怖を生むような教室内の要 素に注意する必要性を示唆する。生徒の望ましい学習 態度を導くには，教師は失敗した場合の恐机や不安を あおることで生徒を動機づけるのではなく, 望む結果 の獲得に積極的に向かっていくよう動機づけることが 重要であるだろう。

しかし尺度の平均得点をみると, 中学生は小学生よ りも失敗恐怖や遂行回避志向の性質を有意に強く示し た。中学校では, テストなどの評価体制が小学校より 統一的になり, 自分の相対的な能力がより明確に判断 できるようになること, また発達にともない, 他人か
らの評価により敏感になることなどが原因として考え られる. 失敗のネガティブな面を強調し, 学校という 学業達成場面を脅威の場と知覚する傾向を強めてしま うことがないよう, 中学生に対しては特に配慮しなけ ればならないといえる。

今後は，新たな概念化に基づく三つの目標志向と他 の多様な環境的な変数や認知的変数との関連性をさら に探る必要があるだろう。

\section{引用文献}

Ames, C. 1992 Classrooms: Goals, structures, and student motivation. Journal of Educational Psychology, 84, 261-271.

Ames, C., \& Ames, R. 1984 Systems of student and teacher motivation: Toward a qualitative definition. Journal of Educational Psychology, 76, 535-556.

Ames, C., \& Archer, J. 1988 Achievement goals in the classroom: Students' learning strategies and motivation processes. Journal of Educational Psychology, 80, 260-267.

Atkinson, J. W. 1957 Motivational determinants of risk-taking behavior. Psychological Review, 64, 359372.

Atkinson, J. W. 1964 An introduction to motivation. Princeton, NJ: Van Nostrand.

Bentler, P. M. 1995 EQS structural equations program manual. Encino, CA: Multivariate Software, Inc.

Covington, M. V., \& Omelich, C. L. 1991 Need achievement revisited: Verification of Atkinson's original $2 \times 2$ model. In C. D. Spielberger, I. G. Sarason, Z. Kulcsar \& G. L. Van Heck (Eds.), Stress and emotion: Anxiety, anger, and curiosity. Vol. 14. Washington, DC: Hemisphere. Pp. 85-105.

Covington, M. V., \& Roberts, B. W. 1994 Self-worth and college achievement: Motivational and personality correlates. In P. Pintrich, D. Brown \& C. Weinstein (Eds.), Student motivation, cognition, and learning. Hillsdale, NJ: Erlbaum. Pp. 157-187.

Duda, J. L., \& Nicholls, J. G. 1992 Dimensions of achievement motivation in schoolwork \& sport. Journal of Educational Psychology, 84, 290-299.

Dweck, C. S. 1986 Motivational processes affecting learning. American Psychologist, 41, 1040-1048.

Elliot, A. J., \& Church, M. A. 1997 A hierarchical model of approach and avoidance achievement motivation. Journal of Personality and Social Psychology, 72, 218-232.

Elliot, A. J., \& Harackiewicz, J. M. 1996 Approach and avoidance achievement goals and intrinsic motivation: A mediational analysis. Journal of Personality and Social Psychology, 70, 461-475.

Gjesme, T., \& Nygård, R. 1970 The Achievement Motives Scale (AMS). Unpublished report, Uni- 
versity of Oslo.

Gray, J.A. 1987 The psychology of fear and stress. 2nd ed. New York: Cambridge University Press.

Hayamizu, T., Ito, A., \& Yoshizaki, K. 1989 Cognitive motivational processes mediated by achievement goal tendencies. Japanese Psychological Research, 31, 179-189.

伊藤 篤 1995 達成目標と動機づけ 新井邦二郎 (編著) 教室の動機づけの理論と実践 金子書房 Pp. 76-91.

(Ito, A.)

Man, F., Nygård, R., \& Gjesme, T. 1994 The Achievement Motives Scale (AMS): Theoretical basis and results from a first try-out of a Czech form. Scandinavian Journal of Educational Research, 38, 209-218.

McClelland, D. C., Atkinson, J.W., Clark, R. A., \& Lowell, E. L. 1953 The achievement motive. New York: Appleton-Century-Crofts.

Middleton, M. J., \& Midgley, C. 1997 Avoiding the demonstration of lack of ability: An underexplored aspect of goal theory. Journal of Educational Psychology, 89, 710-718.

Nicholls, J. G. 1984 Achievement motivation: Con- ceptions of ability, subjective experience, task choice, and performance. Psychological Review, 91, 328-346.

Nolen, S. B. 1988 Reasons for studying: Motivational orientations and study strategies. Cognition and Instruction, 5, 269-287.

Schunk, D. H., \& Swartz, C.W. 1993 Goals and progress feedback: Effects on self-efficacy and writing achievement. Contemporary Educational Psychology, 18, 337-354.

Skaalvik, E. M. 1997 Self-enhancing and selfdefeating ego orientation: Relations with task and avoidance orientation, achievement, self-perceptions, and anxiety. Journal of Educational Psychology, 89, $71-81$.

豊田秀樹 1992 SASによる共分散構造分析 東京 大学出版会

(Toyoda, H. 1992 Covariance structure analysis with SAS. Tokyo: University of Tokyo Press.)

Wolters, C. A., Yu, S. L., \& Pintrich, P. R. 1996 The relation between goal orientation and students' motivational beliefs and self-regulated learning. Learning and Individual Differences, 8, 211-238.

1999.7.23 受稿, 2000.3.4 受理— 